\title{
Antral gastrin cell hyperfunction associated with chronic pancreatitis
}

\author{
Atilla Ertan, mD, Martin S. Litwin, MD, Robert A. Hammer. MD, Paul Vega, mD
}

ABSTRACT: This report describes a patient with antral gastrin cell hyperfunction who also had pancreatic pseudocysts and partial common bile duct obstruction secondary to chronic pancreatitis. A 60 -year-old female had a three-month history of worsening epigastric discomfort with episodes of nausea, vomiting and weight loss. The patient had no history of peptic ulcer disease and no ulcers were demonstrated during diagnostic work-up. Baseline fasting serum gastrins were 715 and $1000 \mathrm{pg} / \mathrm{mL}$ (normal 50 to $170 \mathrm{pg} / \mathrm{mL}$ ). These decreased to $515 \mathrm{pg} / \mathrm{mL}$ during an intravenous secretin test and increased up to $2155 \mathrm{pg} / \mathrm{mL}$ after a protein meal test. The patient also had chronic pancreatitis, multiple pancreatic pseudocysts and a partial common bile duct obstruction. Truncal vagotomy and antrectomy for antral gastrin cell hyperfunction, Roux-en-Y cystjejunostomy for pancreatic pseudocysts and choledochojejunostomy for common bile duct stricture were performed. Three months after the operation, the patient was symptom-free and fasting serum gastrin levels at one week, two months and three months after the surgery were 11,40 and $50 \mathrm{pg} / \mathrm{mL}$, respectively. Can J Gastroenterol 1988;2(3):123-126.

Key Words: Antral gastrin cell hyperfunction, Chronic pancreatitis

Departments of Medicine, Surgery and Pathology, Tulane University Medical School, New Orleans, Louisiana

Correspondence and reprints: Dr Atilla Ertan, Tulane University School of Medicine, Section of Gastroenterology, 1430 Tulane Avenue, New Orleans, Louisiana 70112, USA. Telephone (504) $588-5329$

Received for publication June 1, 1988. Accepted July 21, 1988
A NTRAL GASTRIN CELL HYPERFUNCtion resembling the ZollingerEllison syndrome (ZES) was first described in 1972 (1) and subsequently reported by others $(2-8)$. Other terms such as 'ZES type l' ( 2 ) and 'pseudo-ZES' (5), have been used for this syndrome. Since the volume density of antral $G$ cells has been found to be both increased $(2,5,7)$ and normal $(8)$, and since an increased $G$ cell density can occur in other conditions (9-11), the term antral gastrin cell hyperfunction appears to be most appropriate (12).

The incidence of this entity is unknown, but with refinements of diagnostic procedures, including serum gastrin response to protein meal and intravenous secretin, its recognition is increasing as awareness of its possibility is appreciated. The clinical significance of differentiating between various causes of hypergas- 
trinemia is obvious because their managements are quite different. The clinical associations of antral gastrin cell hyperfunction include basal hypergastrinemia, an exaggerated gastrin response to a protein meal, peptic ulcer disease and the absence of gastrinoma. The purpose of this report is to present a patient with antral gastrin cell hyperfunction without peptic ulcer disease who also had pancreatic pseudocysts and a partial common bile duct obstruction secondary to chronic pancreatitis of unknown etiology.

\section{CASE PRESENTATION}

In May 1987, a 60-year-old white female was admitted to hospital after the sudden onset of acute, sharp, stabbing mid-epigastric pain. She had previously been completely asymptomatic and the present complaints had developed following a heavy meal. The patient was diagnosed as having acute pancreatitis and medical management was begun. Because of epigastric discomfort, esophagogastroduodenoscopy was performed. A 'beefy appearing gastric mucosa wit' edematous folds' was described. There was no ulcer or gastric outlet obstruction. Gastric aspirate $\mathrm{pH}$ was 1.0 by indicator paper and fasting serum gastrin concentration was 1800 $\mathrm{pg} / \mathrm{mL}$. An abdominal computerized tomography (CT) scan showed a mass in the tail of the pancreas. Seven days after admission symptoms had resolved and the patient was discharged on cimetidine $800 \mathrm{mg}$ bid and antacids. A follow-up serum gastrin concentration two weeks later was above $1000 \mathrm{pg} / \mathrm{mL}$ and repeat abdominal CT scan showed persistence of the previously noted pancreatic mass. The patient was referred to Tulane University Medical Center where she was admitted on August 13, 1987 for further study and treatment.

At the time of admission the patient described post prandial epigastric distress associated with a $30 \mathrm{lb}$ weight loss over the previous three months even though there had been no change in her usual good appetite. There was no vomiting or diarrhea and no history of peptic ulcer disease or pancreatic disease. She also denied alcohol and tobacco use and drug abuse. There was no family history of peptic ulcer disease or endocrinopathy. Physical examination was unremarkable except for mid-epigastric tenderness to palpation.

The following laboratory data were reported on admission: hemoglobin 14.1 $\mathrm{g} / 100 \mathrm{~mL}$, hematocrit $41.3 \%$, white blood cell count $5600 / \mathrm{mm}^{3}$ with normal differential, urinalysis normal, stool exam negative for occult blood and negative Sudan-III reaction. Blood urea nitrogen, total serum protein, albumin, liver enzymes, alkaline phosphatase, bilirubin, electrolytes, calcium concentrations and lipid profile in serum, serum and urinary amylase concentrations were within normal limits.

Stimulation tests for serum gastrin were performed by the intravenous administration of secretin $2 \mathrm{U} / \mathrm{kg}$ (Pharmacia, Inc) and by administration of a protein meal. Fasting venous blood samples were taken through an intravenous catheter 15 and 5 mins before secretin injection and then $1,2,5,10,15,30$ and 60 mins after the injection.

Immediately after completion of the secretin test, the patient ate a test meal consisting of three eggs, two slices of bacon, two slices of toast and $8 \mathrm{oz}$ of milk containing $2 \%$ butterfat. The meal contained $34.5 \mathrm{~g}$ protein, $26.6 \mathrm{~g}$ fat and 41.1 g carbohydrate (5). Blood samples were taken $0,5,10,15,30$ and 60 mins after starting the meal. Serum gastrin was measured in all blood samples using a radioimmunoassay technique which specifically measures physiologically active gastrin, both G-17 and G-34 (13). Ele- vated baseline serum gastrin concentrations (715 and $1000 \mathrm{pg} / \mathrm{mL}$ ) decreased (down to $515 \mathrm{pg} / \mathrm{mL}$ ) after intravenous secretin; there was an exaggerated increase (up to $2155 \mathrm{pg} / \mathrm{mL}$ ) after the protein meal (Figure 1). Serum concentrations of prolactin $(11.2 \mathrm{pg} / \mathrm{mL})$, pancreatic polypeptide $(253 \mathrm{pg} / \mathrm{mL})$ and parathyroid hormone $(25 \mu \mathrm{L} \mathrm{Eq} / \mathrm{mL})$ were within normal limits.

Because of the low $\mathrm{pH}$ value of gastric aspirate during the initial esophagogastroduodenoscopy and the patient's significant epigastric discomfort, a gastric secretory study was deferred. However, the serum group I pepsinogen concentration was $200 \mathrm{ng} / \mathrm{mL}$ (normal, 25 to $100 \mathrm{ng} / \mathrm{mL}$ ) and was consistent with increased gastric secretory capacity. Endoscopic retrograde cholangiopancreatography (ERCP) showed a partial obstruction of the intrapancreatic portion of the distal common bile duct. Also noted were dilatation of the proximal common bile duct (approximately 21 $\mathrm{mm}$ in diameter) and intrahepatic bile ducts (Figure 2). The main pancreatic duct was diffusely narrowed and was more prominent in the body and the tail. Contrast extravasation during ERCP was interpreted as representing a pseudocyst in the tail of the pancreas.

Because of the patient's persistent symptoms, surgical exploration was performed on August 17, 1987. No intraabdominal gastrinoma was found. The pancreas was noted to be firm and appeared chronically inflamed. There were two pseudocysts in the body and

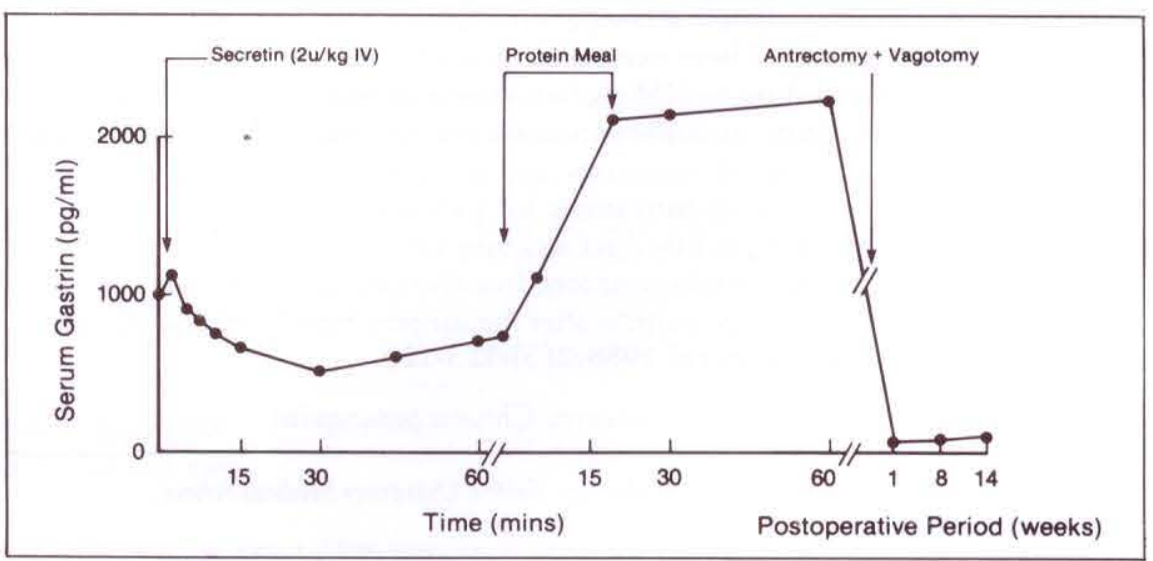

Figure 1) Serum gastrin response to the stimulation tests and after surgery. Elevated baseline serum gastrin decreased to $515 \mathrm{pg} / \mathrm{mL}$ after intravenous secretin test and increased up to $2155 \mathrm{pg} / \mathrm{mL}$ after a protein meal test. The serum gastrin levels returned to normal limits after antrectomy and vagotomy 


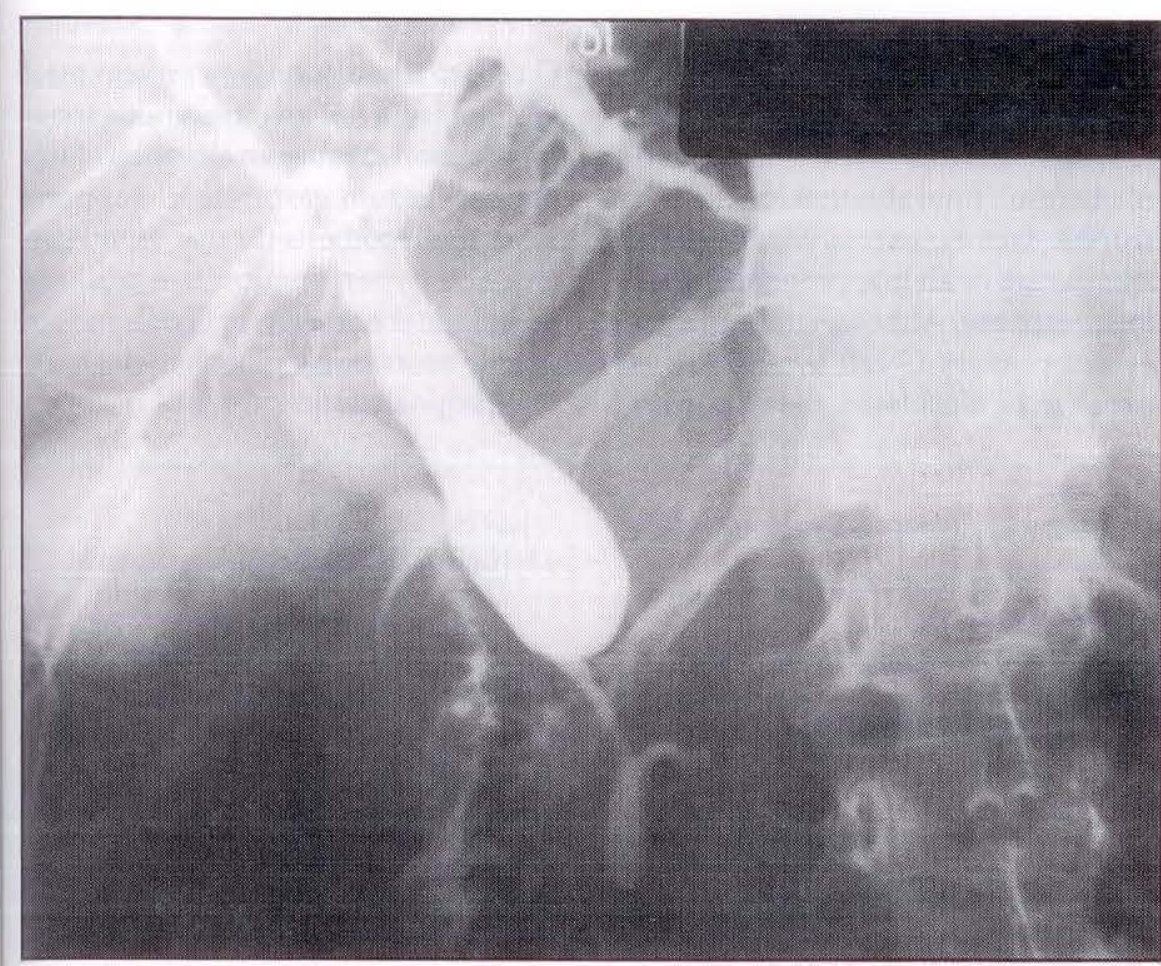

Figure 2) Endoscopic retrograde cholangiopancreatography showed a smooth partial stricture of the distal common bile duct combined with post stricture dilatation of the common bile duct and intrahepatic bile ducts. The main pancreatic duct was diffusely narrowed

tail. The following procedures were performed: pancreatic biopsy; Roux-en-Y pancreaticocystjejunostomy; cholecystectomy; Roux-en-Y choledochojejunostomy; and antrectomy and vagotomy. Pathologic exam of the pancreatic biopsy was consistent with chronic pancreatitis. The gastric antrum showed chronic hypertrophic gastritis, pancreatic acinartype and intestinal metaplasia with $\mathrm{G}$ cell hyperplasia. The gallbladder showed chronic cholecystitis with cholesterolosis. The patient's postoperative course was uneventful. The patient was discharged on August 26, 1987 and has remained well for at least the last five months and is now on pancreatic enzyme therapy and has gained $20 \mathrm{lbs}$. Fasting serum gastrin levels at the end of the first postoperative week, two months and three months after surgery were 11,40 and $50 \mathrm{pg} / \mathrm{mL}$, respectively.

\section{DISCUSSION}

Zollinger-Ellison syndrome has been classified into two types; type 1 , due to antral gastrin cell hyperfunction and type 2, due to a gastrinoma (1). Characteristically, antral gastrin cell hyperfunction viously been treated by vagotomy, a condition known to result in $\mathrm{G}$ cell hyperplasia. The present patient had not had a prior vagotomy to account for this. The authors believe that the patient had antral gastrin cell hyperfunction with a fasting hypergastrinemia and an exaggerated gastrin response to a protein meal. Moreover, the dramatic return of hypergastrinemia to normal after antrectomy and vagotomy suggested that the antrum was the sole source of the excess serum gastrin.

This is the first repor ted case of antral gastrin cell hyperfunction associated with chronic pancreatitis and its complications, such as pancreatic pseudocysts and a partial common bile duct obstruction. Fasting and post prandial hypergastrinemia have been observed in patients with chronic pancreatitis $(14,15)$. This hypergastrinemia may be secondary to chronically reduced gastric acid secretion (14). On the other hand, a more recent study indicated that patients with severe pancreatic insufficiency frequently have had gastric acid hypersecretion (15). However, none of the previous studies showed basal gastrinemia above $400 \mathrm{pg} / \mathrm{mL}$ in these patients $(14,16)$. This association appears to be coincidental in the present case. Despite significant partial stricture of the distal common bile duct combined with dilatation of extra- and intrahepatic bile ducts, the patient's liver function tests were within normal limits.

This is the oldest patient reported with antral gastrin cell hyperfunction $(1-8,12)$. 
Although the previously reported patients had a strong family history of peptic ulcer disease among first degree relatives and had a form of peptic ulcer that was recurrent and resistant to medical management, the present patient had neither previous nor present peptic ulcer disease nor a family history of ulcer disease. One other antral gastrin cell hyper-

ACKNOWLEDGEMENTS: The authors thank Mrs April E.T. Dembrun and Mrs Andrea A. Janssen for their secretarial assistance. This work was supported by Gastroenterology Research Fund \#530569.

\section{REFERENCES}

1. Polak JM, Stagg B, Pearse AGE. Two types of Zollinger-Ellison syndrome: Immunofluorescent, cytochemical and ultrastructural studies of the antral and pancreatic gastrin cells in different clinical states. Gut 1972;13:501-12.

2. Cowley AJ, Dymock IM, Boyes BE, et al. Zollinger-Ellison syndrome type 1: Clinical and pathological correlations in a case. Gut 1973;14:25-9.

3. Gray GR, Gillespie G, Gordon I. Extragastric gastrinoma or G-cell hyperplasia of the antrum? The preoperative diagnosis in a case of hypergastrinaemia. $\mathrm{Br}$ J Surg 1976:63:596-8.

4. Ganguli PC, Polak JM, Pearse AGE, Elder JB, Hagerty M. Antral gastrin cell hyperplasia in peptic-ulcer disease. Lancet $1974 ; 1: 583-6$. function patient was reported to have had no peptic ulcer disease (5).

Antral gastrin cell hyperfunction might result from abnormal or excessive trophic factors, excessive neurogenic stimulation or an inappropriate physiologic response. Although the pathogenesis of primary $\mathrm{G}$ cell hyperplasia remains to be elucidated, the response of

5. Friesen SR, Tomita T. Pseudo-ZollingerEllison syndrome. Hypergastrinemia, hyperchlorhydria without tumor. Ann Surg 1981;194:481-93.

6. Keuppens F, Willems G, De Graef J, et al. Antral gastrin cell hyperplasia in patients with peptic ulcer. Ann Surg 1980;191:276-81.

7. Lewin KJ, Yang K, Ulich T, Elashoff JD, Walsh J. Primary gastrin cell hyperplasia: Report of five cases and a review of the literature. Am J Surg Pathol 1984;8:821-32.

8. Lamers CBH, Ruland CM, Joosten $\mathrm{HJM}$, et al. Hypergastrinemia of antral origin in duodenal ulcer. Dig Dis Sci 1978;23:998-1002.

9. Royston CMS, Polak JM, Bloom SR, et al. G-cell population of gastric antrum, plasma gastrin and gastric acid secretion in patients with and without duodenal ulcer. Gut 1978; 19:689-98.

10. Stave R, Brandtzaeg P. Immunohistochemical investigation of gastrin producing cells (G-cells). Estimation of antral density, mucosal distribution and total mass of $\mathrm{G}$-cells in resected stomachs from patients with peptic ulcer disease. Scand J Gastroenterol
G cells to stimulation by a protein meal and the failure of an intravenous secretin injection to cause an elevation of this patient's serum gastrin level supports Friesen's hypothesis (5) that antral gastrin cell hyperfunction is a primary pathologic abnormality of $\mathrm{G}$ cells and not merely an example of a physiologically inappropriate function.

1978;13:199-203.

11. Nielsen $\mathrm{HO}$, Halken S, Lorentzen M. Quantitative studies of the gastrin producing cells of the human antrum. A methodological study. Acta Pathol Microbiol Immunol Scand (A) 1980;88:255-61.

12. Creutzfeldt W. Gastrointestinal peptides - role in pathophysiology and disease. Scand J Gastroenterol 1982;77 (Suppl 1):4-20.

13. Russell RCG, Bloom SR, Fielding LP, Bryant MG. Current problems in the measurement of gastrin release. $\mathrm{A}$ reproducible measure of physiological gastrin release. Postgrad Med J 1975;52:645-50.

14. Regan PT, Malagelada JR, DiMagno EP, Go VLW. Postprandial gastric function in pancreatic insufficiency. Gut 1979:20:249-54.

15. Gullo L, Corinaldesi R, Casadio R, et al. Gastric acid secretion in chronic pancreatitis. Hepatogastroenterology 1983;30:60-2.

16. Gullo L, Vezzadini P, Ventrucci M, Bonora G, Costa PL, Ferri GL. Serum gastrin in chronic pancreatitis. Am J Gastroenterol 1980;73:33-6. 


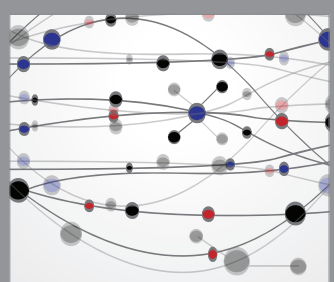

The Scientific World Journal
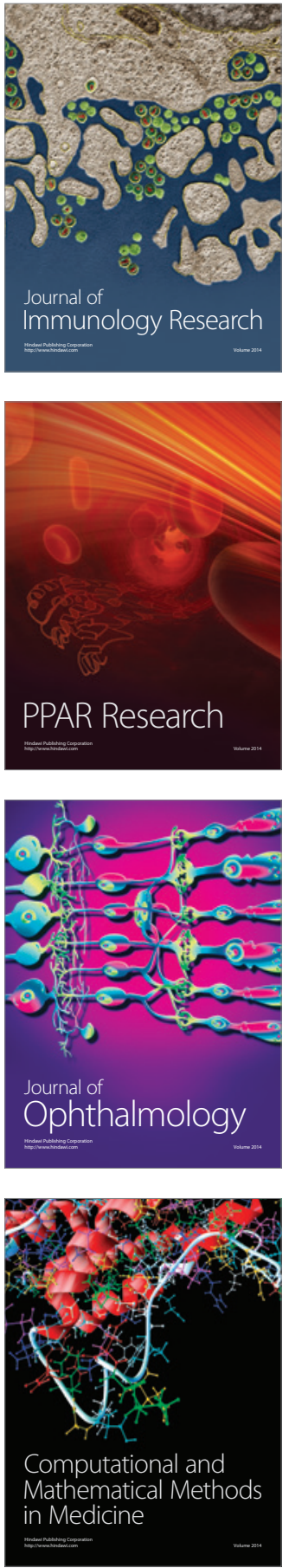

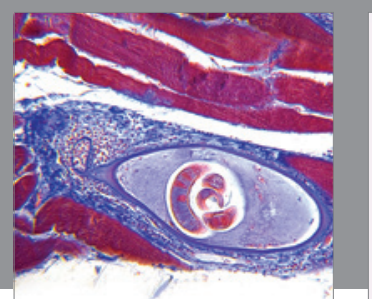

Gastroenterology Research and Practice

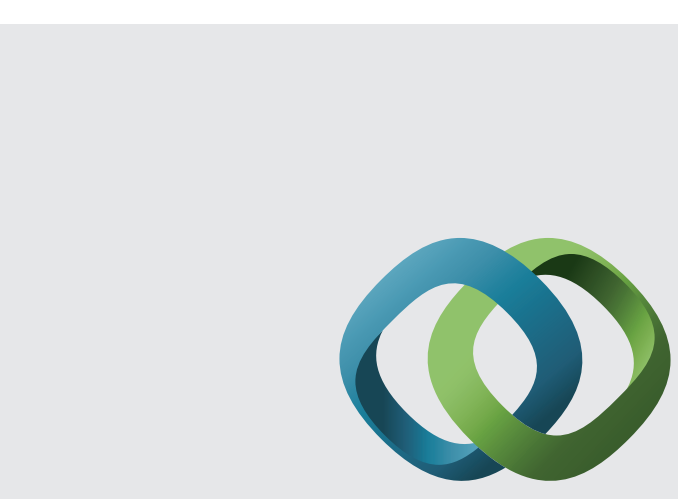

\section{Hindawi}

Submit your manuscripts at

http://www.hindawi.com
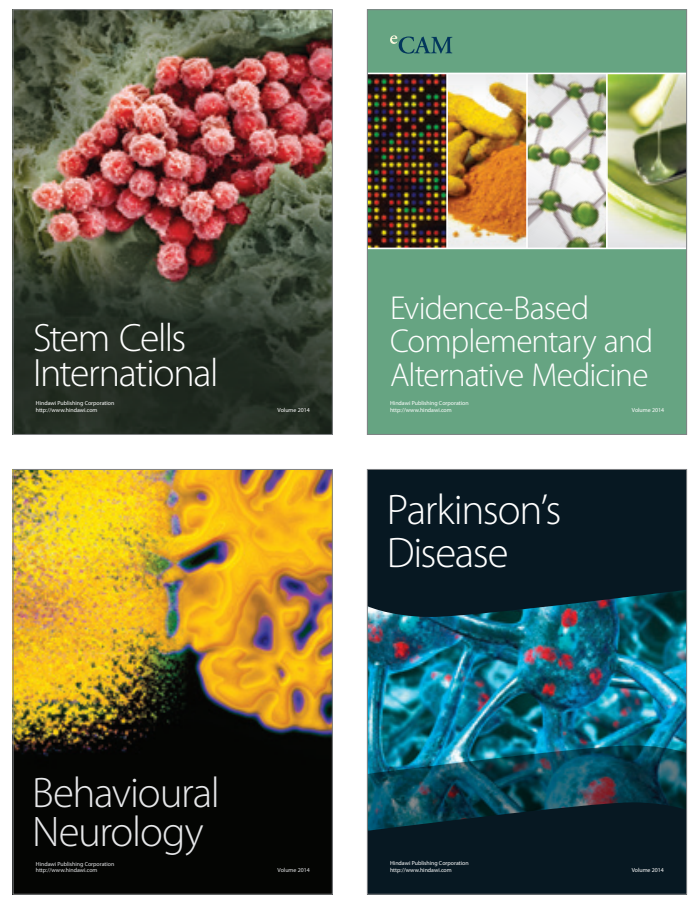
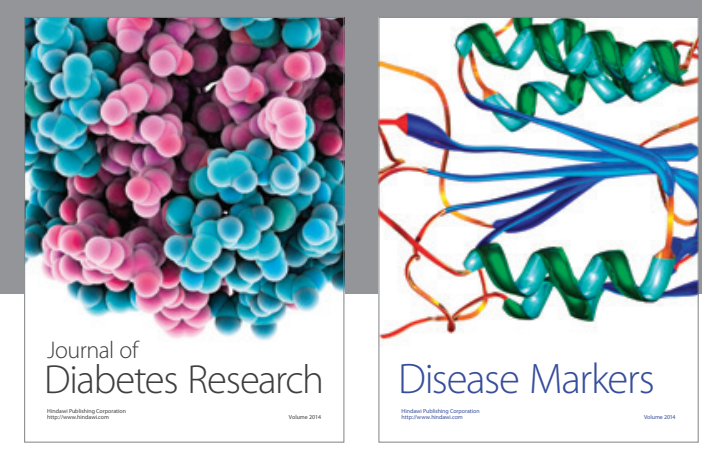

Disease Markers
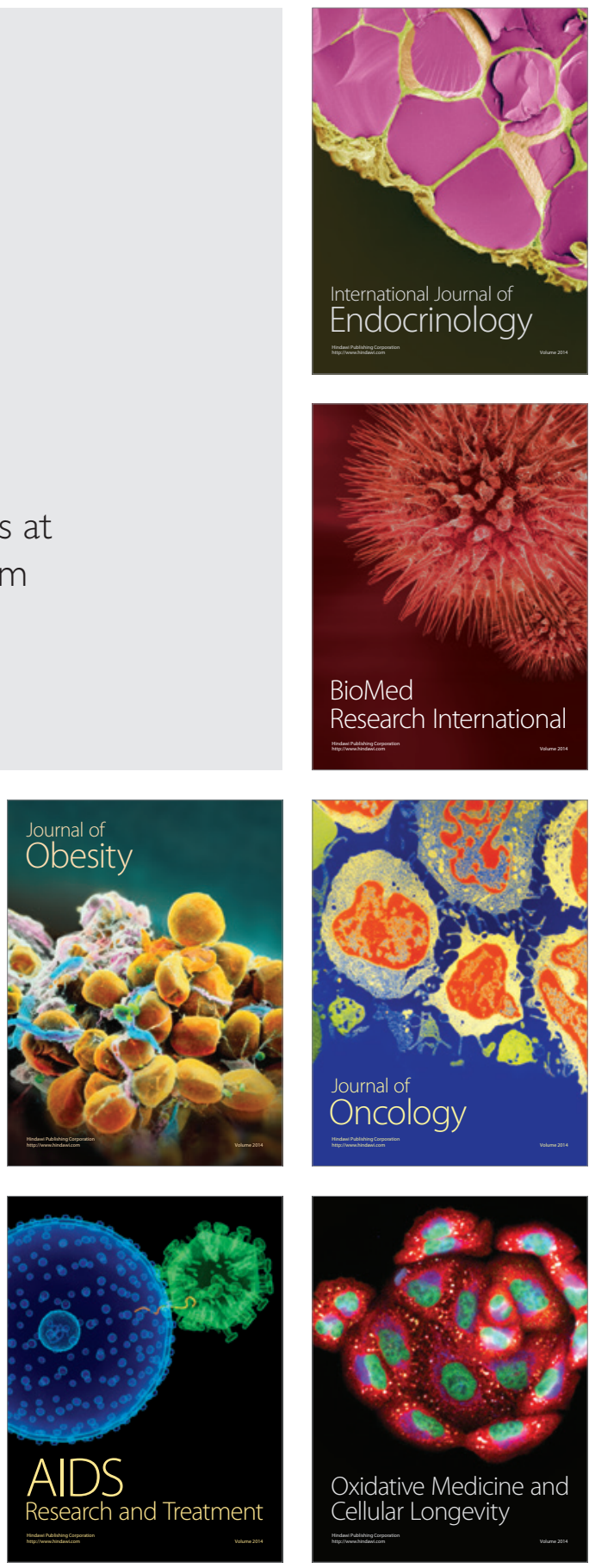